\title{
Assessing Theory and Practice in Competitive Strategy: Challenges and Future Directions
}

Article in Journal of CENTRUM Cathedra · September 2008

DOI: 10.7835 /jcc-berj-2008-0010

\section{CITATIONS}

9

1 author:

\section{John Alan Parnell}

University of North Carolina at Pembroke 129 PUBLICATIONS 1,860 CITATIONS

SEE PROFILE
READS

73

Some of the authors of this publication are also working on these related projects: 
\begin{tabular}{l} 
JCC \\
\hline Journal of \\
\hline CENTRUM \\
\hline Cathedra ${ }^{\mathrm{TM}}$ \\
\hline
\end{tabular}

\title{
Assessing Theory and Practice in Competitive Strategy: Challenges and Future Directions
}

by

\author{
John A. Parnell* \\ Ph. D. in Business Administration, Fogelman College of Business, TheUniversity of Memphis, USA \\ Doctor of Education, School of Education, Campbell University, USA \\ Master of Business Administration, School of Business, East Carolina University, USA \\ Master of Arts in Adult Education, School of Education, East Carolina University, USA
}

\begin{abstract}
Competitive strategy scholars seek to answer three important questions: (a) what constitutes an effective strategy and how is it crafted, (b) how are strategies implemented in an organization, and (c) how can a strategy's effectiveness be evaluated? Three corresponding themes, namely, strategy formulation, execution or implementation, and evaluation or control, permeate the competitive strategy literature. In this paper, nine issues of scholarly and practical relevance in the competitive strategy domain are reviewed and assessed. Collectively, the nine issues reflect the significant progress made in competitive strategy research in recent years and opportunities for further development in the field. Directions for future research are discussed.
\end{abstract}

Keywords: Competitive strategy, strategic consensus, performance measurement, middle management, art versus science, dynamic strategies, strategic risk, sustainability

\section{Assessing Theory and Practice in Competitive Strategy: Challenges and Future Directions}

Considerable research progress has been made over the past three decades in the competitive strategy arena (Capps, Jackson, \& Hazen, 2002; Mauri \& Michaels, 1998; Phelan, Ferreira, \& Salvador, 2002). Nonetheless, a number of challenges remain (Jarzabkowski, 2003; Kim \& Mauborgne, 2005; McDonald, 2006; Van de Ven \& Johnson, 2006). Prevailing topics of concern are of keen interest in both domestic and global contexts (Garrigos-Simon, Marques, \& Narangajavana, 2005; Jusoh \& Parnell, 2008; Rugman \& Verbeke, 2008; Spanos, Zaralis, \& Lioukas, 2004), as well as content and process dimensions (Richter \& Schmidt, 2005; Sorge \& Brussig, 2003; Varadarajan, 1999).
Competitive strategy scholars have sought to answer three important questions. First, questions arise about what constitutes an effective strategy and how to craft an effective strategy. Key competitive strategy issues in this realm involve both process and content concerns (Richter \& Schmidt, 2005; Varadarajan, 1999). Process issues are focused on the nature of strategy, for example, is process an art or a science, as well as whether the strategy is visible or hidden, and the extent to which top managers coalesce around a common strategic approach. Content issues emphasize the defining characteristics of competitive strategies and include traditional efforts anchored in industrial organization (IO) economics that focus on strategic commonalities across businesses (Porter, 1981, 1985), as well as more recent efforts that accentuate each strategy's uniqueness, such as 
the resource-based view (RBV) (Barney, 1991). The recent resurgence in organizational economics, which emphasizes issues such as incentives, agency theory, transactions cost theory, authority and delegation, decentralization, and property rights theory, builds upon both IO and the RBV (Fulghieri \& Hodrick, 2006; Foss \& Foss, 2005; Gibbons, 2003; Kim \& Mahoney, 2005; Whinston, 2003).

A second question is how strategies are implemented in organizations. Prevalent issues in this realm are concerned with contingency, fit, and factors that contribute to a strategy's ultimate effectiveness. Process and content issues are also a focus in this realm, although the distinction between the two categories is not clear (Sorge \& Brussig, 2003; Varadarajan, 1999). Broadly speaking, process issues address the management of strategic risk and the strategic roles played by various members of an organization, most notably the top executives, management teams, and middle managers, in the development and execution of strategy. Content issues include strategic change and the notion of dynamic strategies. The third question concerns the evaluation of the effectiveness of a strategy. Issues of interest are related to strategic control, including measuring performance and sustaining it over the long term. Within this realm, process and content distinctions become even more problematic because the two categories tend to converge (Varadarajan, 1999).

The three questions can be synthesized into three broad phases: Strategy formulation, strategy execution or implementation, and strategy evaluation or control. Although scholars and practitioners are interested in all three phases, they have approached issues in each area from different perspectives. Scholars tend to be concerned with methods of inquiry and analysis and emphasize precision over practical application. Practitioners are more interested in prescriptions pertinent to their particular situations.

The purpose of this paper is to evaluate progress in the competitive strategy arena within the context of the three phases and suggest appropriate directions for future research in the field. Following a brief historical overview of the competitive strategy research traditions, the nine issues of continued interest to scholars and practitioners are discussed (see Table 1). To the extent possible, issues are presented in order from those most closely associated with formulation to those most intricately linked to execution and evaluation. Key scholar and practitioners' perspectives about the issues are also addressed. A discussion of future research directions aimed at building upon the progress made over the past few decades concludes the paper.
Table 1

Process and Content Issues in Competitive Strategy

Artistic and scientific perspectives on strategy

Visible and hidden strategies

Strategic consensus

Classification schemes and typologies

Commitment, flexibility, and dynamic strategies

Managing strategic risk

Middle-management roles in crafting and executing strategies

Designing and executing sustainable strategies

Performance measurement

\section{Competitive Strategy Research Traditions}

Contemporary business strategy research has its roots in the economic tradition of industrial organization. Within Bain (1956) and Masons' (1939) IO framework of industry behavior, firm profitability is viewed as a function of industry structure. Characteristics of the industry, not the firm, are viewed the primary influences on firm performance. The IO framework has been questioned, although Bain and Masons' basic structure-conductperformance model is most appropriate for industries with uncomplicated group structures, high concentrations, and relatively homogeneous firms (Seth \& Thomas, 1994). Early strategy researchers challenged the IO perspective, noting its inability to explain large performance variances within a single industry. The strategic group level of analysis was proposed as a middle ground between the deterministic, industry level of analysis proposed and developed by IO economists and the organizational level of analysis studied by strategic management researchers (Hergert, 1983; Porter, 1981).

Strategic group assessments identified clusters of businesses employing similar strategies. Business strategy typologies identifying several generic strategic approaches were developed and used as a theoretical basis for identifying strategic groups. Although strategic groups are an industry-specific phenomenon, many strategic group researchers began to use approaches believed to be generalizable across industries, specifically those proposed by Porter $(1980,1985)$ and Miles and Snow $(1978,1986)$.

According to Porter's (1980, 1985) framework, a business can maximize performance either by striving to be the low-cost producer in an industry or by differentiating its line of products or services from those of its rivals. Either of the approaches may be accompanied by focusing organizational efforts on a given segment of the market. 
Miles and Snow's (1978) alternative framework identified four strategic types: prospectors, defenders, analyzers, and reactors. Prospectors perceive the environment as dynamic and uncertain. They maintain flexibility and employ innovation to combat environmental change, often becoming the industry designers (Miles \& Snow, 1986). Defenders perceive the environment to be stable and certain, and seek stability and control in their operations to achieve maximum efficiency. Analyzers stress both stability and flexibility, attempting to capitalize on the best of both of the preceding strategic types. Reactors lack consistency in strategic choice and perform poorly (Brunk, 2003).

The majority of empirical work testing Miles and Snow's (1986) typologies has been supportive (Allen \& Helms, 2006; Moore, 2005; O’Regan \& Ghobadian, 2006). Scholars have also proposed a number of different competitive typologies over the past two decades, some distinctive and others based on previously developed frameworks (Garrigos-Simon et al., 2005; Goh, 2006; Nwokah, 2008). Nonetheless, the original versions of the typologies remain among the most widely cited and tested (Eng, 1994; Wright, Kroll, Pringle, \& Johnson, 1990).

In the 1970s and early 1980s, economists also began to augment the traditional economic perspective by integrating the role of incentives (Williamson, 1985). Traditional assumptions that managers act rationally to maximize firm profit were challenged by arguments rooted in psychology, sociology, and other disciplines (Barney \& Ouchi, 1986; Kim \& Mahoney, 2005). The agency problem, for example, addressed the notion that executives do not always share the goals of shareholders when making strategic decisions for a firm. Hence, the economic perspective expanded to fill some of the gaps left by previous work in the field, invoking strict assumptions that in many instances were not accurate reflections of reality (Williamson, 2005).

Meanwhile, dissatisfaction with the IO foundation inherent in strategic group analysis may have been the primary impetus for an interest in firm resources, not strategic group membership, as the foundation for firm strategy (Barney, 1991; Collis, 1991; Grant, 1991). The resulting paradigm, built on the earlier work of Penrose (1959) and Wernerfelt (1984), emphasized unique firm competencies and resources in strategy formulation, implementation, and performance. Proponents of the resource-based view studied firm-level issues such as transaction costs (Camerer \& Vepsalainen, 1988), economies of scope, and organizational culture (Barney, 1991; Fiol, 1991). Key business-level issues included competitive imitation (Rumelt, 1984), informational asymmetries (Barney, 1986), causal ambiguities (Reed \& DeFillippi, 1990), and the process of resource accumulation (Dierickx \& Cool, 1989). Although resource-based theory represents a distinct view of a firm, it draws from many of the same traditions as the broader perspective of organizational economics (Barney \& Ouchi, 1986).
Within the RBV, the nature of competitive advantage began to gain renewed prominence. From the RBV perspective, competitive advantage occurs when a firm is implementing a value creating strategy not simultaneously implemented by any current or potential rivals (Peteraf, 1993). Sustained competitive advantage exists when competitors are unable to duplicate the benefits of the strategy over time (Barney, 1991).

Inits simplestform, theIO-resource-based theorydebate can be reduced to a single question: Are organizational factors more or less important than industry factors in determining firm performance? Henderson and Mitchell (1997) suggested that attempting to answer this question might be a fruitless exercise because organizational capabilities, competition, strategy, and performance are fundamentally endogenous. In a similar vein, McGahan and Porter (1997) found that industry accounted for $19 \%$ of the variance in profitability within specific SIC categories, and that the difference varied substantially across industries. Powell (1996) suggested that industry accounts for between $17 \%$ and $20 \%$ of performance variance. Hence, any attempt to build on the merits of both the IO and resource-based perspectives must account for the varying degrees of influence of both industry factors and firm resources on performance (Roquebert, Phillips, \& Westfall, 1996; Spanos et al., 2004).

Accepting the transitory nature of resources that lead to competitive advantage is a key concern for the RBV (Dess, Gupta, Hennart, \& Hill, 1995; Feurer \& Chaharbaghi, 1994; Robins \& Wiersema, 1995). Critics acknowledge the intuitive appeal of a resource-based perspective, but argue that it does not offer a prescriptive approach (Sheehan \& Foss, 2007). Hence, the increasing speed of business activity and the notion of ephemeral competitive advantage have prompted researchers to emphasize dynamic strategy positioning models (Chung, Chan \& Leung, 2006; Foss \& Ishikawa, 2007b). Dynamic strategy positioning models do not refute the tenets of $\mathrm{IO}$, organizational economics, or the RBV per se, but challenges static assumptions in favor more flexible and adaptive approaches. This is especially true for industries where success depends on a constant flow of new offerings (Barnett, 2006; Fiegenbaum \& Thomas, 2004; Selsky, Goes, \& Baburoglu, 2007).

In recent years, organizational economics, or integrating perspectives such as agency theory, incentives, transaction costs theory, and even property rights theory, experienced a resurgence in the literature (Fulghieri \& Hodrick, 2006; Foss \& Foss, 2005; Gibbons, 2003; Whinston, 2003). Scholars in the organizational economics school integrate the tools and theories originally established for the industry level of analysis with new insights and approaches more appropriate for the firm level (Sheehan \& Foss, 2007).

Interest is organizational economics is not limited to issues with strong traditional ties to the economics field. 
Challenges associated with managing managers, for example, are strategic to human resource management concerns. The organizational economics perspective sheds new light on the issue by viewing senior management as a key resource that to be attracted, developed, and harvested. By incorporating transaction costs, agency theory, and other corporate governance concerns into the analysis, scholars are expanding the boundaries of the competitive strategy field (Boxall \& Gilbert, 2007). Organizational economics therefore provides the potential for an integrative, comprehensive framework for understanding strategies in organizations (Kim \& Mahoney, 2005).

\section{Artistic and Scientific Perspectives on Strategy}

Strategy formulation is linked to the top executive's personal philosophy and personality (Kotey \& Meredith, 1997). Members of managements' self-interest, personalities, interpretations, and influences on strategy have also been examined (Guth \& MacMillan, 1986; Janis, 1972; Smircich, \& Stubbart, 1985). Examining the strategy formulation process without considering the personal and philosophical idiosyncrasies of managers is shortsighted (Foss, 2007a). The art-science debate is a fundamental issue because the perception of the strategy phenomena and the process of strategy formulation are key building blocks of strategy. In other words, one's view of how the strategy process should function is inseparable from one's view of the strategy's content. In formal terms, the debate was initiated with Mintzberg's (1987) conceptualization of synthetic and analytic approaches to strategy.

The difference between the art and science interpretations of strategy is substantial. The art proponents hold that the lack of environmental predictability and the fast pace of change render elaborate strategy planning unreliable. Rather than focusing on scientific models, strategists should incorporate extensive creativity and intuition in order to design a comprehensive strategy for the firm (Ford \& Gioia, 2000). In contrast, followers of the science perspective see the business environment as largely objective, analyzable, and at least somewhat predictable. Hence, strategic managers should follow a systematic process of environmental, competitive, and internal analysis and build the organization's strategy on a scientific foundation.

The strategy literature has traditionally favored the science or planning model. As such, strategic managers systematically assess the firm's external environment and formulate strategy. The search for causal relationships and objectivity are central to the process. By definition, strategic managers should be trained, highly skilled analytical thinkers capable of digesting a myriad of objective data and translating that data into a desired direction for the firm.

In contrast, Mintzberg's (1987) notion of a craftsman, which encompasses individual skill, dedication, and perfection through mastery of detail, embodies the artistic model. The strategist senses the state of the organization, interprets its subtleties, and seeks to mold its strategy, as if a potter molding clay. The artist visualizes the outcomes associated with various alternatives and ultimately charts a course based on holistic thinking, intuition, and imagination.

The relevance of the art-science philosophical debate is clear. Those following the science perspective typically minimize or reject altogether the role of imagination and creativity in the strategy process and are not generally receptive to alternatives that emerge from any process other than a comprehensive, analytical approach. Proponents of the artistic perspective may view strategic planning exercises as time poorly spent. In addition, those who view strategy as an art may not be as likely as those who view strategy as a science to make the effort necessary to maximize the value of a formal planning process (Hamel, 1996; Hoffman, 2001).

\section{Visible and Hidden Strategies}

The extent to which a firm should clarify the content of its competitive strategy has been a topic of keen interest in recent decades. The existence of a clear, recognizable strategy has its advantages. Customers appreciate knowing what a company is attempting to accomplish and prospective investors tend to hesitate when they do not have a clear vision of the firm's position and future priorities. Sharing strategic information with lower level managers and employees may enhance both job comprehension and organizational commitment.

Arguments can be made against a free dissemination of strategy, however. Open discussion to external stakeholders, for example, middle managers, investors, community leaders, and so on, may translate easily into competitive intelligence for rival firms. Participants in the strategy process become more attractive to other industry players and may be lured away for competitive reasons. For this reason, most strategic managers argue for at least some degree of privacy with respect to firms' strategies.

The Chinese warrior Sun Tzu is cited as an historical proponent of the hidden strategy perspective (Michaelson, 2001). In the military context, he argued all war is based on deception and that effective military maneuvers are ones that are not easily predicted by one's opponent. Business strategists, therefore, surmise that the best strategy must be one that competitors cannot understand. Sharing strategic information with stakeholders ultimately aids rivals of the firm.

To argue with the notion of deceptive strategies is difficult. The problem is that strategic secrecy may not only keep a strategy hidden from those who might wish to exploit it, but also from those who can contribute to its development or who are responsible for executing it. 
However, in an environment where managers frequently move from one firm to another, forthright strategic discussion with employees may ultimately result in the sharing of confidential strategic intentions with competitors. In addition, effective communication with investors and business media can support a firm's stock price, although it can involve the dissemination of sensitive information.

Agency concerns are relevant, however. For as long as absentee owners, or shareholders, have been hiring professionals to manage their companies, questions have been raised concerning the degree of emphasis hired managers actually place on maximizing financial returns. The agency problem refers to a situation in which a firm's managers, or the agents of the owners, fail to act in the best interests of shareholders. The extent to which the problem adversely affects most firms is widely debated, and factors associated with the problem can vary across nations and cultures (Hirshleifer, Jensen, Hall, Shleifer, \& Meckling, 1994; Ramaswamy, Veliyath, \& Gomes, 2000). The prospective link between the agency problem and strategy proliferation should not be ignored (Davidson, Worrell, \& Nemec, 1998; Denise, Denis, \& Sarin, 1997, 1999).

Ideally, executives would involve all key individuals in the organization, as well as other key stakeholders, such as suppliers, customers, and so forth, in the strategic management process without disseminating key knowledge to those who may have a current or potential competitive interest against the firm. Although this balancing act is difficult, distinguishing the most critical and confidential data and decisions from that which is of little value or cannot be concealed is central to the process. As a practical compromise, executives could identify a narrow scope of data and competitive intelligence that should remain with top managers and take steps to ensure that confidential information is not disseminated beyond the inner circle.

\section{Strategic Consensus}

Executives do not formulate and execute strategies in isolation of others members of the firm. Hence, scholars have begun to consider how others in the organization, most notably members of the top management team, work together to create strategic visions and craft strategies. Empirical research supports the idea that decision quality improves when entrepreneurial teams with diverse backgrounds converge and agree on a course of strategic action (West, 2007).

The notion of strategic consensus addresses the extent to which the members of the top management team agree on a strategy, but can also include other executives and middle managers in the process (Certo, Lester, Dalton, \& Dalton, 2006; Goll, Johnson, \& Rasheed, 2008; Thomas \& Ramaswamy, 1996). If consensus is linked to performance (Andersen, Denrell, \& Bettis, 2007; Bowman \& Ambrosini, 1997), some competitive strategies may be associated with greater agreement among managers.
For example, consensus may be high among focused organizations where everyone seems to understand the niche being targeted by the business, but low among prospectors where the essence of the strategy is not well understood (Wooldridge \& Floyd, 1990). Strategy coherence, or the consistency of strategic choices across business and functional levels, has also been linked to performance (Nath \& Sudharshan, 1994).

The process by which strategic consensus is pursued is a key concern. Specifically, scholars and practitioners are undecided as to whether strategy formulation should emanate from the top and flow downward or whether it should be developed throughout the organization and rise to the top (Brady \& Walsh, 2008; Chakravarthy \& Larange, 2008). Top-down proponents argue that seasoned executives are the only ones in the organization with the collective experience, acumen, and fiduciary responsibility required to chart the strategy. In contrast, bottom-up proponents argue that because middle- and lower-level managers implement strategy, they should play a central role in its development (Frese, van Gelderen \& Ombach, 2000; Liedtka, 2000; Thorpe \& Morgan, 2007).

Most survey-based competitive strategy studies measure strategy content and/or performance by surveying a top executive, often the CEO, while ignoring other members of the top management team, as well as managers at middle and lower levels. Although such studies assume that CEO accounts of strategy are accurate, the over-reliance on CEO perceptions has been challenged. Golden (1992) found that 58\% of CEO's he surveyed did not agree with the previously validated accounts of their organizations' past strategies.

Inputs into the strategic management process also extend well beyond the top executive, including organizational variables and personal attributes (Bowen, 1987; Chaganti \& Sambharya, 1987; Kotey \& Meredith, 1997). Aspects of the strategy-making process and the content of business strategies may also mediate the organizational context and structure relationship. Management's self-interest, personalities, interpretations, and influences on strategy have also been examined (Boyett \& Currie, 2004; Guth \& MacMillan, 1986; Janis, 1972; Smircich \& Stubbart, 1985).

\section{Classification Schemes and Typologies}

A key research concern with respect to the theme of strategy identification involves classification schemes and typologies (Goh, 2006). Validity and reliability issues began to take prominence when Porter (1980) and others began to propose business strategy typologies three decades ago. A firm's competitive strategy can be a complex and subjective phenomenon. Linking strategy categories with consistent measures remains a challenge for scholars.

Three primary means of identifying, or measuring, competitive strategies exist. First, researchers can infer 
the strategy from accounting data, assuming that a firm cannot conceal its strategy from its financial data. For example, a firm with a relatively high ratio of advertising expenditures to sales may be categorized as following a marketing-oriented strategy. Proponents of this approach emphasize the objectivity associated with the approach.

Second, scholars can survey executives concerning the strategy orientation of the firm. Proponents of the approach note that strategy is a qualitative phenomenon that is not subject to quantitative assessment. Critics, however, charge that top executives opinions do not always agree with the actions or views of other members of the top management team (Golden, 1992).

Third, researchers can examine all available data, including financial statements, personal interviews, and articles written by third parties. This is the most time consuming approach and does not eliminate subjectivity. However, proponents of the "expert" approach argue that it is the most thorough means of assessing strategy.

Regardless of whether financial, perceptual, or other data is used, cluster analysis has been a prominent tool of strategic group researchers for classifying businesses into strategic groups, especially in early studies (Cool \& Schendel, 1988; Derajtys, Chrisman, \& Bauerschmidt, 1993). Nonetheless, the technique has been challenged on empirical grounds (Barney \& Hoskisson, 1990; Ketchen \& Shook, 1996; Thomas \& Venkatraman, 1988). Hatten and Schendel (1977) cautioned that the application of factor analysis or clustering algorithms to discover strategic groups assumes that these groups actually exist. Barney and Hoskisson (1990) demonstrated that any clustering algorithm would produce a set of clusters when applied to industry data. These categories, however, do not necessarily constitute strategic groups. The question as to whether strategic groups actually exist or whether they are simply artifacts of the algorithms used to generate clusters remains unanswered. More recently, researchers have begun to emphasize the importance of classification schemes used in configuration studies (Davis \& Schul, 1993; Dess, Newport, \& Rasheed, 1994; Zahra, 1993).

Cluster analysis has also been challenged on conceptual grounds. Specifically, critics have noted that the technique concentrates on similarities and does not account for strategy differences. Proponents of the RBV argue that forcing classifications based on any limited sets of generic strategies is inconsistent with an emphasis on firm resources. Although early studies (e.g., Dess \& Davis, 1984) suggested a link between strategic group membership and performance, not all cluster studies have supported the association. Katobe and Duhan (1993) identified three strategy clusters among Japanese businesses, namely, brand skeptics, mavericks, and true believers, and found that membership of one group was not a significant predictor of performance. Rather, organization situational variables such as the degree of emphasis on manufacturing and profitability moderate the link between strategy and performance.
Today, cluster analysis is considered useful in some exploratory and descriptive studies, but is not commonly used in theory and model testing. Although more advanced and precise statistical methods are now available, the fundamental problem illustrated by the application and subsequent criticism of cluster analysis remains. Because a firm's competitive strategy is unique, constantly changing (at least to some extent), and multifaceted, measurement is a complex task. Even with advances in theory and methods, studies testing the competitive strategy-performance link must make assumptions about the nature of strategy. Hence, additional work in the strategy classification realm is required.

\section{Commitment, Flexibility, and Dynamic Strategies}

Executives may choose to commit to a strategy for an extended period and enjoy the benefits of organizational learning and a clear customer image. Alternatively, and consistent with the notion of dynamic strategies, executives can maintain flexibility so that the organization does not become committed to products, technology, or market approaches that may become outdated. In a perfect world, organizations commit to predictable, successful courses of action, and strategic change is only incremental. In the real world, however, outcomes are not always predictable, and the environment constantly changes (Grewel \& Tansuhaj, 2001).

Those who favor a high degree of strategic consistency make four primary arguments. First, strategic inaction can minimize risk and uncertainty. Even successful changes may not be short-lived when competitors are able to mimic the shift (Wernerfelt \& Karnani, 1987). Further, a potentially successful strategic change must endure efforts to return to the former strategy when those whose careers may suffer because of the change resist executing the strategy (Akingbola, 2006; Gaertner, 1989). Strategic change can challenge the assumptions of all organizational members and may be difficult to implement even with employee support (Boyett \& Currie, 2004).

Second, it is likely that the measures required to implement a change in strategy may be very costly. For example, a shift from a prospector or analyzer strategy to a defender strategy may require investments in sophisticated production equipment to lower production costs, a characteristic more important to effective implementation of a defender strategy (Miles \& Snow, 1978). Likewise, a shift from a defender or analyzer strategy to a prospector strategy may require outlays to develop or enhance research and development facilities. In addition, the benefits of the investment do not always accrue accordingly. Indeed, competitors often take a "free ride" (Lieberman \& Montgomery, 1988). Large firms can afford to enjoy the ride because they possess the resources to respond effectively when necessary (Wernerfelt \& 
Karnani, 1987). Indeed, one business may subsidize a change that leads to benefits for the entire industry.

Third, changes in competitive strategies can confuse consumers. For example, if a business employing a low cost strategy attempts to switch to a differentiation strategy, its price-oriented customers may become confused and leave in pursuit of another low cost leader, while those customers willing to pay a premium price for differentiated products may not recognize the organization's strategic change. Many will likely recall remnants of the previous strategy, perhaps from advertising campaigns, and may not even consider a transaction with the organization.

Finally, even when strategic change results in a successful new product or service, no assurance exists that the success is sustainable; rivals may imitate the firm, distort consumer perceptions, and reap the benefits of the initial strategic change (Foxman, Muehling, \& Berger, 1990). In the case or product changes, consumers purchase the imitation product thinking it is the original (Loken, Ross, \& Hinkle, 1986).

Researchers who emphasize high strategic flexibility make four primary arguments. First, a strategy should be aligned with the environment. Environmental alignment is difficult without strategic flexibility when an organization cannot adapt to its changing external environment (Parnell, 1997). Even if alignment exists, an environmental shift may necessitate strategic change to maintain it. Hence, changes in competition and technology necessitate a change in the knowledge base within the organization if it is to survive (Hannan \& Freeman, 1977; Ulrich, 1987; Whipp, Rosenfeld, \& Pettigrew, 1989). The state of the environment is not always fully understood by strategy formulators, and top managers may likely contemplate a strategic change when environmental uncertainty is high (Wernerfelt \& Karnani, 1987).

Second, an organization can seek first-mover advantages by entering a new market or developing a new product or service prior to the competition (Gannon, Smith, \& Grimm, 1992; Petersen \& Welch, 2000). Being a first mover can help secure access to scarce resources, increase the organization's knowledge base, and result in substantial long-term competitive advantage, especially when switching costs are high (Lieberman \& Montgomery, 1988). However, the extent to which the first-mover factor can affect firm activity and performance depends on a number of factors. First-mover advantages tend to be greatest when competitors are roughly the same size and possess similar resources (Wernerfelt \& Karnani, 1989). When this is not the case, large competitors that possess vast resources can afford to wait while others make initial investments, subsequently responding to market successes with greater reach, superior distribution channels, and economies of scale. When small competitors become the first movers and are successful, larger firms can still enter the market successfully (Mascarenhas, 1992).

Third, it is argued that an organization must modify its strategy as its unique set of resources change (Acedo \& Florin, 2007; Barney, 1991). The RBV suggests that competitive advantage often occurs from such organizational attributes as informational asymmetries (Barney, 1986), culture(Fiol, 1991), resource accumulation (Dierickx \& Cool, 1989), and the minimization of transaction costs (Camerer \& Vepsalainen, 1988), and that strategies should reflect changes in these capabilities. Resource shifts necessitating strategic change may be more prevalent in some organizations than in others (Hitt, Keats, \& DeMarie, 1998). Likewise, strategic change can improve an organization's ability to adapt by forcing healthy changes within the business. Organizations that maintain strategic consistency over time may become stagnant, limiting the creativity and potential contributions of their human resources.

Fourth, strategic changes may be necessary if performance declines. Indeed, declining profitability is the most common catalyst for strategic change (Webb \& Dawson, 1991). Organizational performance, age, and length of tenure of the founding entrepreneur influence the degree to which a founding strategy endures and thus, the prospects for strategic change. New CEOs are often recruited to attempt strategic changes upon entering the organization (Greiner \& Bhambri, 1989).

Recent changes in the business landscape lend support to the flexibility argument. For example, outsourcing, or contracting out a firm's non-core, non-revenue-producing activities to other organizations, primarily (but not always) to reduce costs has become more widespread in recent years. When implemented properly, outsourcing can cut costs, improve performance, and refocus the core business. Offshoring involves the relocation of some or all of a firm's manufacturing or other business processes to another country and enables the firm to retain control of the operations. Advances in the Internet and related technologies have reduced the cost and complexity of outsourcing and offshoring efforts, enabling firms to retain flexibility and shift strategies more effectively without completely reorganizing their operations (Barthelemy, 2003; Fairclough, 2006).

In sum, the extent to which a trade-off exists between the two priorities is not clear (Grewel \& Tansuhaj, 2001). When traditional firms perform poorly, their strategic managers are exhorted to promote flexibility and strategic renewal to improve profitability. In contrast, when strategic change is not successful, pundits challenge the firm to return to its core business. Hence, the strategic commitment-flexibility issue remains unresolved and may benefit from additional inquiry.

\section{Managing Strategic Risk}

Strategy is about making choices (Porter, 1985), some of which appear to be riskier than others are. Environmental scanning is at best an inexact science, and inevitably, 
strategic managers are left with varying amounts of risk and uncertainty associated with each strategic alternative they possess. Some scholars emphasize that strategy formulation is inherently risky, and top managers should not forego attractive opportunities because of a lack of certainty (Acedo \& Florin, 2007). Others, however, suggest that risk reduction is the primary responsibility of top management. Executives, therefore, should be skilled at processing information so that risk can be avoided, or at least severely minimized, in strategy formulation. Embracing risk, they argue, will inevitably lead to failure (Ghemawat \& Khanna, 2000).

Strategic managers have a number of analytical and qualitative techniques at their disposal to transform their strategic environments in the direction of certainty (Leavy, 2007). Strategic managers must identify key decision criteria and then develop systematic resources to glean current and reliable data that can readily drive these decisions. Inevitably, some strategies succeed while others fail. From one perspective, successful strategies can be associated with effective risk management, while unsuccessful strategies can be linked to a lack of competitive intelligence. Alternatively, success can be understood as a function of luck, a construct conceptually linked to risk.

The notion of strategic risk infers a role played by luck, or the existence of chance and some degree of unpredictability of outcomes. The role of luck in firm performance can be viewed from three broad perspectives. First, luck may play little or no role in strategic success, a view consistent with scientific inquiry's assumption of causality (Kovenklioglu \& Greenhaus, 1978) and the perspective that a belief in luck is irrational (Day \& Maltby, 2003). Second, luck may be seen as influencing performance in one or a few iterations, but the laws of averages and probability ensure that it plays little or no role over an extended period. Consider that the best hitters in baseball may perform poorly for a few games, but they will outperform the others over the course of a season through normal variation. This view is also broadly consistent with scientific inquiry because it largely ignores the role of luck, at least in the end. Finally, what is often called luck may play a significant role in the long term either by generating short-term success that fortuitously positions a firm for superior performance in the long term or by directly creating long-term success through a series of "lucky" endeavors. Complexity theory has shown that many processes are highly sensitive to initial conditions so that one unexpected event may be amplified disproportionately over time (Dooley, 1997).

Competitive intelligence, introduced in a previous section, is also related to the notion of strategic risk management (Brummer, Badenhorst, \& Neuland, 2006). Timely tactical information can assist executives in making effective strategic decisions (Culver, 2006; Service, 2006). More specifically, high quality competitive intelligence can become an integral part of the strategy itself (Fahey, 2007). Ultimately, practitioners must seek to reduce risk as much as is feasible and, at the same time, collect and process as much competitive intelligence as practicable. Risk reduction and competitive analysis remains a complex challenge in today's rapidly changing business environments.

\section{Middle Management Roles in Crafting and Executing Strategy}

Most scholars agree that at least some middle and lower level managers should be involved in formulating strategy. A key concern, however, is the most appropriate degree of involvement. Some scholars argue that seasoned executives are the only ones in the organization with the collective experience, acumen, and fiduciary responsibility required to chart the strategy. Moreover, the potential for expanded agency problems exists when the strategy formulation process relies heavily on contributions from middle managers who are more likely to be further removed from ownership than top managers (Davidson et al., 1998; Hirshleifer et al., 1994; Ramaswamy et al., 2000).

Because middle and lower level managers execute strategies, it seems logical that they should play a central role in the development of strategy. Indeed, recent research has emphasized the role of multiple managers in building the superior performing organization (Markoczy, 2001; Rouleau, 2005; Wooldridge \& Floyd, 1990). Although the concept of middle-management involvement in strategy is not a recent phenomenon, effective strategies often reflect a diverse array of top- and middle-management inputs, particularly in global markets (Boyett \& Currie, 2004; Westphal \& Fredrickson, 2001). Mintzberg and Waters' (1985) notion of deliberate and emergent strategies acknowledged the significant role of top and middle managers in the strategic management process. Strategy synchronization is a team effort, requiring contributions and knowledge from both middle and senior managers (Pappas \& Wooldridge, 2007).

The notion of increased subordinate participation in decision making has received greater attention in recent years (Boyett \& Currie, 2004). Perhaps executives should establish the strategy because they have the expertise and experience to "see the big picture." However, the increased education of the workforce at all levels and the general trend toward decentralization over the past two decades suggest that a strict top-down approach may not yield the best strategy. Executives should exhibit strategic leadership and accept full responsibility for the strategic management of the organization. However, progressive firms augment the reality with systems that encourage the input of middle and lower level managers, and even nonmanagers, to the extent to which they are willing and able to contribute. 
The link between organizational learning and strategy development is a key concern. When strategic managers view learning as a continuous process and place greater value on human capital, they are more likely to foster the creation of knowledge that is unique to the firm and can represent a prime source of competitive advantage (Trim $\&$ Lee, 2007). The value of a firm's human capital is linked inexorably to the organization's strategic posture (Mailath, Nocke, \& Postlewaite, 2004). If the expectation is that middle managers participate in the strategy process, especially in the formulation phase, they must develop the skills and personal capabilities necessary to move beyond individual considerations and contemplate what is best for the organization as a whole.

\section{Designing and Executing Sustainable Strategies}

Generating profits in the current term is only a partial indicator of success. Firms must be able to sustain profitability over time and account for residual affects, positive and negative, on their environments. Specifically, strategic sustainability refers to the extent to which an action deemed successful in one period can sustain or enjoy similar success in future periods. The notion of sustainability has been used in a variety of contexts, including competitive advantage (Barney, 1991), ecology (Stead \& Stead, 2000; Stead \& Stead, 2004), and even quality management (Svensson, 2006).

Two broad realms of sustainability exist. Market sustainability refers to the extent to which a strategy's success can achieve a desired level of financial performance while enduring current and potential change across competitors and markets. In general, this form of sustainability is consistent with the notion of "sustainable competitive advantage" inherent in the resource based theory of the firm (Barney, 1991). Environmental sustainability refers to the extent to which a strategy's success is compatible with the firm's general environment over the long term. Environmental sustainability considerations include issues such as the natural environment and the ecology, politicallegal and regulatory concerns, and crisis management (Parnell, 2008). Studies that address one of these types of sustainability tend to avoid the other type, with some exceptions (Sangle \& Babu, 2006, 2007).

Sustainable strategic management (SSM) integrates these two realms and refers to the strategies and related processes associated with the continuity of superior performance, broadly defined, from both market and environmental perspectives (Parnell, 2008). SSM's distinctiveness becomes obvious when considering the link between the two types of sustainability. When market sustainability and environmental sustainability are examined simultaneously, however, three broad possibilities emerge. First, a strategy that embodies only market sustainability regardless of its environmental sustainability potential is potentially useful only in the short term. Whether or not the strategy is environmentally sustainable has relatively little importance because the strategy is not sustainable from a market perspective. Its effectiveness, if any, is transitory.

Second, when a strategy possesses only market sustainability, it is compromising some degree of the environment in favor of traditional firm performance. Such scenarios have sparked scholarly interest in fields ranging from biology to business ethics (Stead \& Stead, 1994). This situation is most threatening to society because the same strategy that presents an environmental threat also generates firm profits, thereby fostering its perpetuation.

Third, an ideal competitive strategy embodies both market sustainability and environmental sustainability. Organizations pursuing such a strategy can sustain competitive and market changes with an approach that manages external resources appropriately; neither what succumbs to nor invites government regulation and minimizes potential losses from unexpected organizational crises. Developing this type of strategy is elusive because doing so often assumes that organizations formed specifically to pursue market sustainability will voluntarily balance the pursuit of market sustainability with environmental sustainability (Lee \& Ball, 2003).

Additional research and clarity is required with respect to strategies that are sustainable from both perspectives. SSM research must balance a commitment to both the need for a vibrant free market system and the recognition that what is "best for business" in the short term is not always desirable for society. Addressing both concerns may require various trade-offs (cf. Porter, 1996), but the validity of such an assertion remains untested.

The extent to which current strategic management models and approaches can be adapted to an SSM perspective is open to debate. In a perfect world, organizations commit to predictable, successful courses of action and multiple objectives are achieved. A perfect world is difficult to accomplish, however, because outcomes are not always predictable and the environment is constantly changing (Grewel \& Tansuhaj, 2001).

\section{Measuring Organizational Performance}

Studies touting a link between competitive strategies and firm performance must address how performance is best measured. Indeed, a clear and effective system of performance measurement is a powerful mechanism for fostering successful strategy execution. Such a system would be required to include all indicators of performance that are relevant for the existence of an organization and the means by which it achieves success and growth (Hillman \& Keim, 2001; Kaplan \& Norton, 1996; Latinen, 2002). Although no consensus exists on the specifics surrounding the measurement of organizational 
performance, some scholars have suggested that different measures are appropriate for different strategies (Dye, 2004; Van der Stede, Chow, \& Lin, 2006).

Today many organizations are employing multiple measures of performance, as opposed to the single profitability measures used in the past. Kaplan and Norton (1996) developed a comprehensive performance measurement system known as the balanced scorecard (BSC), a multidimensional approach that includes financial and nonfinancial measures. Because communicating business strategy and aligning individual goals with corporate goals are critical in many organizations, a BSC approach can provide a means for communication and alignment of corporate strategies by cascading and linking measures to each level of organization, including business units, support units, and employees (Jusoh \& Parnell, 2008).

Balanced scorecards may include three types of performance measures. The first and most common means of measurement is using financial measures. Accounting data such as return on assets (ROA), return on investment (ROI), and return on sales (ROS) have been applied in numerous studies (Bromiley, 1986; Daily, McDougall, Covin, \& Dalton, 2002; Jacobson, 1987; Palepu, 1985). Proponents of using financial measures emphasize the objectivity associated with comparing the performance level of various business units along standardized lines. Although such measures do not result in the valid valuation of intangible assets (Huselid, 1995), financial measures remain a common, widely accepted approach in strategy-performance studies (Jusoh \& Parnell, 2008).

Second, market-based measures of performance have received considerable attention in the literature (Amit \& Livnat, 1988; Lubatkin \& Rodgers, 1989; Lubatkin \& Shrieves, 1986; Kyriazis \& Anastassis, 2007). Economic value added (EVA) and market value added (MVA) have been touted as the most accurate means of evaluating how well a firm creates shareholder wealth (Dutta \& Reichelstein, 2005; Zaima, Turetsky, \& Cochran, 2005).

Third, qualitative measures include subjective areas of performance such as ethical behavior, stakeholder satisfaction with performance, customer satisfaction, and management satisfaction with performance. Viewing performance through a nonfinancial lens can provide insight into organizational processes and outcomes that cannot be seen via financial measures (Parnell, O'Regan, \& Ghobadian, 2006).

As performance measurement systems like the BSC become more sophisticated and comprehensive, it is more important for organizations to provide appropriate incentives to foster accurate reports of performance. Research has linked performance distortions to incentive systems that directly or indirectly encourage managers to be less than truthful (DeHoratius \& Raman, 2007; Kaarboe \& Olsen, 2008).

Continued debate is likely. Indeed, the performance measure(s) selected can have a significant influence on the results of studies linking strategies with performance (Cavalieri, Gaiardelli, \& Ierace, 2007; Dye, 2004; Pongatichat \& Johnston, 2008; Venkatraman \& Ramanujam, 1986). The most valid means of measuring performance involves multiple methods, although such an approach can be time consuming and cumbersome (Atkinson, 2006).

\section{Conclusions \& Future Research Directions}

In this paper, nine key issues of research and practical concern within the context of the three phases of competitive strategy, namely, formulation, execution, and evaluation, were identified and discussed. Several limitations deserve recognition. The nine issues discussed are not proposed as an all-encompassing representation of the field, but reflect how the field has progressed over the past few decades and shed light on key challenges facing researchers. Moreover, the emphasis in the paper was on issues related to the competitive, namely, business level of analysis. Topics at the corporate levels, for example, governance, diversification, and mergers, and the functional levels, for example, tactics, integration, and quality, are also valid concerns but these concerns were not addressed in the paper.

Some of the issues addressed, such as the art-science and visible-hidden debates, draw attention to the somewhat subjective perspectives that underpin how researchers and practitioners view the nature of the competitive strategy field. Other issues, such as sustainable strategic management and performance measurement, represent unresolved questions that concern specific factors or processes. Those issues with more of a subjective or philosophical nature tend to be more closely associated with strategy formulation, thus reinforcing the notion that the early stages in the strategy process are largely intuitive (Hoffman, 2001).

Four broad research concerns or directions were identified. The first involved the proper sphere of competitive strategies as a research field. As demonstrated, the domain encompasses a variety of influences, including economics, organization theory, behavioral management, and a body of knowledge distinct to the field. Scholars from disparate fields can collaborate to address many of these key issues.

The renewed interest in organizational economics represents such an effort (Fulghieri \& Hodrick, 2006; Foss \& Foss, 2005; Gibbons, 2003; Whinston, 2003). Scholars in this school are applying the economist's tools to strategy issues that cross-traditional, disciplinary lines, such as the role of incentives in managing the firm (Sheehan \& Foss, 2007). Organizational economics appears to have expanded to provide an integrative, comprehensive framework for understanding the field (Kim \& Mahoney, 2005). 
Second, a need for resolution along a number of lines exists. Consider the art-science debate as an example. Although unresolved in practice, substantial evidence exists to support both viewpoints. Indeed, following a comprehensive process of strategy development and implementation is likely to improve the prospects for success. A comprehensive process may be more critical for businesses that face low levels of uncertainty (Courtney, Kirkland, \& Viguerie, 1997). However, the creative dimensions of strategy, such as brainstorming and qualitative forecasting, are also important. Strategic managers should follow a systematic strategic management model while recognizing that the steps in the model are neither all encompassing nor specifically sequential.

Most problematic is the notion that executives who adopt the strategy-as-art perspective may not be willing to consider findings associated with the planning perspective. New or modified planning approaches will likely be seen as cumbersome, academic exercises devoid of practical relevance. In this case, researchers can strengthen the relevance and acceptance of their findings by addressing concerns directly and if possible, incorporating aspects of the alternative perspectives into their research designs and/or considerations of managerial implications that emanate from their work.

Third, the integration across these nine issues is clear. What constitutes an effective strategy depends on how effectiveness is measured (Dutta \& Reichelstein, 2005). Strategy execution is easier when the appropriate strategy is crafted. When top managers agree on the proper strategic direction for the firm, execution is likely to occur more smoothly at the middle management level (Boyett \& Currie, 2004; Rouleau, 2005).

In a similar vein, classifying issues along the lines of formulation, execution, and evaluation is becoming more difficult. For example, the role of middle managers in the strategy process, once prominently associated with the execution phase, has become a key consideration in the formulation phase as well. With the increased pace of change in the business environment, traditional strategic planning models with sequential concerns for formulation, implementation, and control accentuate the reality that all three processes tend to occur simultaneously, especially in mature organizations. The emphasis has shifted from a regimented, categorical approach to one that highlights strategic thinking, effective decision making, and rapid response (Pappas \& Wooldridge, 2007).

Likewise, the content-process distinction has also become cumbersome in recent years. Many strategic problems must be addressed from multiple perspectives concurrently. For example, the appropriate approach for constructing a strategy depends on the proposed general strategic direction. Businesses eschewing a traditional business strategy orientation in favor of a dynamic strategy approach may require greater strategic involvement from middle and lower level managers (Chung et al., 2006;
Foss \& Ishikawa, 2007b). Hence, a more pronounced need exists to marry content and process considerations (Richter \& Schmidt, 2005; Sorge \& Brussig, 2003; Varadarajan, 1999).

The final research direction involves the appropriate balance between theory and practice. At its best, strategic management represents an applied field grounded in theory that represents a myriad of perspectives. Recent efforts, such as organizational economics, draw from multiple disciplines (Kim \& Mahoney, 2005). Although theoretical development is a tedious, often time-consuming process, competitive strategy research that proposes and tests new approaches in a timely manner is critical if the field is to influence practice. Empirical research has been productive, but it has not resolved many of the core strategic dilemmas faced by top executives (Hambrick \& Fredrickson, 2001).

The strategic management field has been replete with concerns about its practical relevance (Gopinath \& Hoffman, 1995). According to critics, research that cannot provide strategic managers with improved decisionmaking abilities does not serve one of the field's primary constituencies (cf. Dacko \& Sudharshan, 1996). The increased rate of technological change and the strategic premium it places on speed and responsiveness create challenges for strategy research designed to influence practice.

Each of the issues discussed in the paper requires further scholarly development if valid practical implications are to follow. Focusing solely on conceptual challenges, however, limits the field to an academic domain devoid of useful analysis and practical recommendations. It is important to resolve key conceptual and research issues while facilitating progress in the practical process and content areas built on existing, emerging theory (Franklin, 2004). Although the problem is not unique to the competitive strategy field, it continues to be a serious one nonetheless.

\section{References}

Acedo, F. G., \& Florin, J. (2007). Understanding the risk perception of strategic opportunities: A tripartite model. Strategic Change, 16(3), 97-116.

Amit, R., \& Livnat, J. (1988). Diversification and the risk-return tradeoff. Academy of Management Journal, 31(issue), 154165.

Akingbola, K. (2006). Strategic choices and change in nonprofit organizations. Strategic Change, 15(6), 265-281.

Allen, R. S., \& Helms, M. M. (2006). Linking strategic practices and organizational performance to Porter's generic strategies. Business Process Management Journal, 12, 433-454.

Andersen, T. J., Denrell, J., \& Bettis, R. A. (2007). Strategic responsiveness and Bowman's risk-return paradox. Strategic Management Journal, 28, 407-429.

Atkinson, H. (2006). Strategy implementation: A role for the balanced scorecard? Management Decision, 44, 1441-1460. 
Bain, J. S. (1956). Barriers to new competition. Cambridge, MA: Harvard University Press.

Bain, J. S. (1968). Industrial organization (2nd ed.). New York: Wiley.

Baker, G. P., Gibbons, R., \& Murphy, K. J. (2008). Strategic alliances: Bridges between "islands of conscious power." Journal of Japanese \& International Economies, 22, 146163.

Barnett, M. L. (2006). Finding a working balance between competitive and communal strategies. Journal of Management Studies, 43, 1753-1773.

Barney, J. B. (1986). Strategic factor markets: Expectations, luck, and business strategy. Management Science, 32, 12311241.

Barney, J. B. (1991). Firm resources and sustained competitive advantage. Journal of Management, 17, 99-120.

Barney, J. B., \& Hoskisson, R.E. (1990). Strategic groups: Untested assertions and research proposals. Managerial and Decision Economics, 11, 187-198.

Barney, J. B., \& Ouchi, W. G. (1986). Organizational economics. San Francisco: Jossey-Bass.

Barthelemy, J. (2003). The seven deadly sins of outsourcing. Academy of Management Executive 17(2), 87-98.

Boxall, P., \& Gilbert, J. (2007). The management of managers: A review and conceptual framework. International Journal of Management Reviews, 9(2), 95-115.

Bowen, H. P., \& Wiersma, M. F. (1999). Matching method to paradigm in strategy research: Limitations of cross-sectional analysis and some methodological alternatives. Strategic Management Journal, 20(7), 625-636.

Bowen, M. G. (1987). The escalation phenomenon reconsidered: Decision dilemmas or decision errors. Academy of Management Review, 12, 52-66.

Bowman, C., \& Ambrosini, V. (1997). Perceptions of strategic priorities, consensus and firm performance. Journal of Management Studies, 34, 241-258.

Boyett, I., \& Currie, G. (2004). Middle managers molding international strategy: An Irish start-up in Jamaican telecoms. Long Range Planning, 37, 51-66.

Brady, M., \& Walsh, A. (2008). Setting strategic direction: A top down or bottom up process? Business Strategy Series, 9(1), 5-11.

Bromiley, P.(1986). Corporate capital investments: A behavioral approach. New York: Cambridge University Press.

Brummer, H. L., Badenhorst, J. A., \& Neuland, E. W. (2006). Competitive analysis and strategic decision-making in global mining firms. Journal of Global Business and Technology, 2(2), 26-38.

Brunk, S. E. (2003). From theory to practice: Applying Miles and Snow's ideas to understand and improve firm performance. Academy of Management Executive, 17(4), 105-108.

Camerer, C., \& Vepsalainen, A. (1988). The economic efficiency of corporate culture. Strategic Management Journal, 9, 115-126.

Capps, C. J., III, Jackson, G. K., \& Hazen, S. E. (2002). Strategic management synergy in the $21^{\text {st }}$ century. Journal of Applied Management and Entrepreneurship, 7(1), 76-93.
Cavalieri, S., Gaiardelli, P., \& Ierace, S. (2007). Aligning strategic profiles with operational metrics in after-sales service. Review of International Journal of Productivity and Performance Management, 56, 436-455.

Certo, S. T., Lester, R. H., Dalton, C. M., \& Dalton, D. R. (2006). Top management teams, strategy and financial performance: A meta-analytic examination. Journal of Management Studies, 43, 813-839.

Chaganti, R., \& Sambharya, R. (1987). Strategic orientation and characteristics of upper management. Strategic Management Journal, 8, 393-401.

Chakravarthy, B., \& Lorange, P. (2008). Driving renewal: The entrepreneur-manager. Journal of Business Strategy, 29(2), 14-21.

Chung, W. W. C., Chan, M. F. S., \& Leung, T. S. (2006). A framework of performance modeling for dynamic strategy. International Journal of Business Performance Management, $8(1), 62-76$.

Collis, D. J. (1991). A resource-based analysis of global competition: The case of the bearings industry. Strategic Management Journal, 12, 49-68.

Cool, K., \& Schendel, D. (1988). Performance differences among strategic group members. Strategic Management Journal, 9207-213.

Courtney, H., Kirkland, J., \& Viguerie, P. (1997). Strategy under uncertainty. Harvard Business Review, 75(6), 67-79.

Culver, M. (2006). Using tactical intelligence to help inform strategy. Strategy \& Leadership, 34(6), 17-23.

Dacko, S. G., \& Sudharshan, D. (1996). Managers will find academic journals helpful. Marketing news, 30(21), 10.

Daily, C. M., McDougall, X. X., Covin, J. G., \& Dalton, D. R. (2002). Governance and strategic leadership in entrepreneurial firms. Journal of Management, 28, 387-412.

Davis, P. S., \& Schul, P. L. (1993). Addressing the contingent effects of business unit strategic orientation on relationships between organizational context and business unit performance. Journal of Business Research, 27, 183-200.

Day,L., \& Maltby, J. (2003). Beliefin good luck and psychological well-being: The mediating role of optimism and irrational beliefs. Journal of Psychology, 137(1), 99-110.

DeHoratius, N., \& Raman, A. (2007). Store manager incentive design and retail performance: An exploratory investigation. Manufacturing \& Service Operations Management, 9, 518-534.

Denis, D. J., Denis, K. D., \& Sarin, A. (1999). Agency theory and the influence of equity ownership structure on corporate diversification strategies. Strategic Management Journal, 20, 1071-1076.

Denis, D. J., Denis, K. D., \& Sarin, A. (1997). Agency problems, equity ownership, and corporate diversification. Journal of Finance, 52(issue), 135-160.

Derajtys, J. M., Chrisman, J. J., \& Bauerschmidt, A. (1993). The shakeout in microcomputers: Causes and consequences. Long Range Planning, 26, 86-97.

Dess, G. G., \& Davis, P. S. (1984). Porter's generic strategies as determinants of strategic group membership and performance. Academy of Management Journal, 26, 467-488. 
Dess, G. G., Gupta, A., Hennart, J. F., \& Hill, C. W. L. (1995). Conducting and integrating strategy research at the international, corporate, and business levels: Issues and directions. Journal of Management, 21, 357-393.

Dess, G. G., Newport, S., \& Rasheed,A. M. (1993). Configuration research in strategic management. Journal of Management, 19, 775-795.

Dierickx, I., \& Cool, K. (1989). Asset stock accumulation and sustainability of competitive advantage. Management Science, 35, 1504-1511.

Dooley, K. J. (1997). A complex adaptive systems model of organizational change. Nonlinear Dynamics, Psychology, and Life Sciences, 1(1), 69-97.

Dutta, S., \& Reichelstein, S. (2005). Stock price, earnings, and book value in managerial performance measures. Accounting Review, 80, 1069-1100.

Dye, R. (2004). Strategy selection and performance measurement choice when profit drivers are uncertain. Management Science, 50, 1624-1637.

Eng, L. G. (1994). Using generic strategies: Some caveats. Singapore Management Review, 16(1), 43-48.

Fahey, L. (2007). Connecting strategy and competitive intelligence: Refocusing intelligence to produce critical strategy inputs. Strategy \& Leadership, 35(1), 4-12.

Fairclough, G. (2006, November). Chinese Cadillac offers a glimpse of GM's future. Wall Street Journal, pp. B1, B4.

Feurer, R., \& Chaharbaghi, K. (1994). Defining competitiveness: A holistic approach. Management Decision, 32, 49-58.

Fiegenbaum, A., \& Thomas, H. (2004). Strategic risk and competitive advantage: An integrative perspective. European Management Review, 1(1), 84-95.

Fiol, C. M. (1991). Managing culture as a competitive resource: An identity-based view of sustainable competitive advantage. Journal of Management, 17, 191-211.

Ford, C. M., \& Gioia, D. A. (2000). Factors influencing creativity in the domain of managerial decision making. Journal of Management, 26, 705-732.

Foss, K., \& Foss, N. J. (2005). Resources and transaction costs: How property rights economics furthers the resource-based view. Strategic Management Journal, 26, 541-553.

Foss, N. (2007a). Strategic management belief. Strategic Organization, 5, 249-258.

Foss, N. (2007b). Towards a dynamic resource-based view: Insights from Austrian capital and entrepreneurship theory. Organization Studies, 28, 749-772.

Foxman, E. R., Muehling, D. D., \& Berger, P. W. (1990). An investigation of factors contributing to consumer brand confusion. Journal of Consumer Affairs, 24, 170-189.

Franklin, P. (2004). Problematics in management theory and practice. Strategic Change, 13, 383-404.

Frese, M., van Gelderen, M., Ombach, M. (2000). How to plan as a small scale business owner: Psychological process characteristics of action strategies and success. Journal of Small Business Management, 38(2), 1-18.

Fulghieri, P., \& Hodrick, L. S. (2006). Synergies and internal agency conflicts: The double-edged sword of mergers.
Journal of Economics \& Management Strategy, 15, 549576.

Gaertner, K. N. (1989). Winning and losing: Understanding managers' reactions to strategic change. Human Relations, 42, 527-545.

Gannon, M. J., Smith, K. G., \& Grimm, C. (1992). An organizational information-processing profile of first movers. Journal of Business Research, 25, 231-241.

Garrigos-Simon, F. J., Marques, D. P., \& Narangajavana, Y. (2005). Competitive strategies and performance in Spanish hospitality firms. International Journal of Contemporary Hospitality Management, 17(1), 22-38.

Ghemawat, P., \& Khanna, T. (2000). Tricon Restaurants International: Globalization re-examined. Boston: Harvard Business School Press.

Gibbons, R. (2003). Team theory, garbage cans and real organizations: Some history and prospects of economic research on decision-making in organizations. Industrial and Corporate Change, 12, 753-787.

Goh, A. L. S. (2006). Towards an effective strategy model: Conceptual development and qualitative assessment of an integrative typology. International Journal of Management \& Decision Making, 7(2/3), 234-253.

Golden, B. R. (1992). The past is the past-Or is it? The use of retrospective accounts as indicators of past strategy. Academy of Management Journal, 35, 848-860.

Goll, I., Johnson, N. B., \& Rasheed, A. A. (2008). Top management team demographic characteristics, business strategy, and firm performance in the US airline industry: The role of management discretion. Management Decision, 46, 201-222.

Gopinath, C., \& Hoffman, R. C. (1995). The relevance of strategy research: Practitioner and academic viewpoints. Journal of Management Studies, 32, 575-594.

Grant, R. M. (1991). The resource-based theory of competitive advantage: Implications for strategy formulation. California Management Review, 33(3), 114-135.

Greiner, L. E., \& Bhambri, A. (1989, Summer). New CEO intervention and dynamics of deliberate strategic change. Strategic Management Journal, 10, 67-86.

Grewel, R., \& Tansuhaj, P. (2001). Building organizational capabilities for managing economic crisis: The role of market orientation and strategic flexibility. Journal of Marketing, 65(2), 47-80.

Guth, W.D., \& Macmillan, I.C. (1986). Strategy implementation versus middle management self-interest. Strategic Management Journal, 7, 313-327.

Hambrick, D. C., \& Fredrickson, J. W. (2001). Are you sure you have a strategy? Academy of Management Executive, 15(4), 48-59.

Hamel, G. (1996). Strategy as revolution. Harvard Business Review, 74(4), 69-82.

Hannan, M., \& Freeman, J. (1977). The population ecology of organizations. American Journal of Sociology, 82, 929-964.

Hatten, K. J., \& Schendel, D. E. (1977). Heterogeneity within an industry: Firm conduct in the U.S. brewing industry, 19521971. Journal of Industrial Economics, 26, 97-112. 
Henderson, R., \& Mitchell, W. (1997, Summer). The Interactions of organizational and competitive influences on strategy and performance. Strategic Management Journal, 18(Special Issue), 5-14.

Hergert, M. L. (1983). The incidence and implications of strategic groupings in U.S. manufacturing industries. Unpublished doctoral dissertation, Harvard University, Boston.

Hillman, A. J., \& Keim, G. D. (2001). Shareholders, stakeholders and social issue. Strategic Management Journal, 22(issue), 125-139.

Hirshleifer, J., Jensen, M. C., Hall, R. E., Shleifer, A., \& Meckling, W. H. (1994). Economics and organizational innovation. Contemporary Economic Policy, 12(2), 1-20.

Hitt, M. A., Keats, B. W., \& DeMarie, S. M. (1998). Navigating in the new competitive landscape: Building strategic flexibility and competitive advantage in the $21^{\text {st }}$ century. Academy of Management Executive, 98(12), 22-42.

Hoffman, B. (2001). What makes a strategy brilliant? Business Horizons, 44(4), 13-20.

Huselid, M. A. (1995). The impact of human resource management practices on turnover, productivity, and corporate financial performance. Academy of Management Journal, 38, 635-672.

Jacobson, R. (1987). The validity of ROI as a measure of business performance. American Economic Review, 778, 470-478.

Janis, I. L. (1972). Victims of groupthink. Boston: HoughtonMifflin.

Jarzabkowski, P. (2003). Strategic practices: An activity theory perspective on continuity and change. Journal of Management Studies, 40, 23-55.

Jusoh, R., \& Parnell, J. A. (2008). Competitive strategy and performance measurement in the Malaysian context: An exploratory study. Management Decision, 46, 5-31.

Kaarboe, O. M., \& Olsen, T. E. (2008). Distorted performance measures and dynamic incentives. Journal of Economics \& Management Strategy, 17(1), 149-183.

Kaplan R. S., \& Norton, D. P. (1996). The balanced scorecard: Translating strategy into action. Cambridge, MA: Harvard Business School Press.

Kaplan, R. S., \& Norton, D. P. (1997). Why does business need a balanced scorecard? Journal of Cost Management, 11, 5-10.

Katobe, M., \& Duhan, D. F. (1993). Strategy clusters in Japanese markets: Firm performance implications. Journal of the Academy of Marketing Science, 21, 21-31.

Ketchen, D. J., \& Shook, C. L. (1996). The application of cluster analysis in strategic management research: An analysis and critique. Strategic Management Journal, 17, 441-458.

Kim, W. C., \& Mauborgne, X. X. (2005). Blue ocean strategy: From theory to practice. California Management Review, 47(3), 105-121.

Kim, J., \& Mahoney, J. T. (2005). Property rights theory, transaction costs theory, and agency theory: An organizational economics approach to strategic management. Management and Decision Economics, 26, 223-242.

Kotey, B., \& Meredith, G. G. (1997). Relationships among owner/manager personal values, business strategies, and enterprise performance. Journal of Small Business Management, 32(2), 37-61.

Kovenklioglu, G., \& Greenhaus, J. H. (1978. Causal attributions, expectations, and task performance. Journal of Applied Psychology, 63, 698-705.

Kyriazis, D., \& Anatassis, C. (2007). The validity of the economic value added approach: An empirical application. European Financial Management, 13(1), 71-100

Laitinen, E. K. (2002). A dynamic performance measurement system: evidence from small Finnish technology companies. Scandinavian Journal of Management, 18, 65-99.

Leavy, B. (2007). Managing the risks that go with high-impact strategies in uncertain markets. Strategy \& Leadership, 25(4), 43-46.

Lee, K., \& Ball, R. (2003). Achieving sustainable corporate competitiveness: Strategic link between top management's (green) commitment and corporate environmental strategy. Greener Management International, 44, 89-104.

Lieberman, M. B., \& Montgomery, D. B. (1998). First-mover (dis)advantages: Retrospective and link with the resourcebased view. Strategic Management Journal, 19(12), 11111125.

Liedka, J. (2000). In defense of strategy as design. California Management Review, 42(3), 8-30.

Loken, B., Ross, I., \& Hinkle, R. L. (1986). Consumer confusion of origin and brand similarity perceptions. Journal of Public Policy and Marketing, 5, 195-211.

Lubatkin, M., \& Rogers, R. C. (1989). Diversification, systematic risk, and shareholder return. Academy of Management Journal, 32(2), 454-465.

Lubatkin, M., \& Shrieves, R. E. (1986). Towards reconciliation of market performance measures to strategic management research. Academy of Management Review, 11(3), 497-512.

Mailath, G. J., Nocke, V., \& Postelwaite, A. (2004). Business strategy, human capital, and managerial incentives. Journal of Economics \& Management Strategy, 13, 617-633.

Markoczy, L. (2001). Consensus formation during strategic change. Strategic Management Journal, 22, 1013-1031.

Mascarenhas, B. (1992). First mover effects in multiple dynamic markets. Strategic Management Journal, 13, 237-243.

Mason, E. S. (1939. Price and production policies of large-scale enterprises. American Economic Review, 29, 61-74.

Mauri, A. J., \& Michaels, M. P. (1998). Firm and industry effects within strategic management: An empirical examination. Strategic Management Review, 19, 211-219.

McDonald, M. (2006). Strategic marketing planning: Theory and practice. Marketing Review, 6, 375-418.

McGahan, A. M., \& Porter, M. E. (1997, Summer). How much does industry matter, really? Strategic Management Journal, 18(Special Issue), 15-30.

Michaelson, G. A. (2001). Sun Tzu: The art of war for managers-Fifty strategic rules. New York: Adams Media.

Miles, R. E., \& Snow, C. C. (1978). Organizational strategy, structure, and process. New York: West.

Miles, R. E., \& Snow, C. C. (1986). Organizations: New 
concepts for new forms. California Management Review, $18(3), 62-73$.

Mintzberg, H. (1987). Crafting strategy. Harvard Business Review, 65(4), 66-75.

Mintzberg, H., \& Waters, J. A. (1985). Of strategies, deliberate and emergent. Strategic Management Journal, 6, 257-272.

Moore, M. (2005). Towards a confirmatory model of retail strategy types: An empirical test of Miles and Snow. Journal of Business Research, 58, 696-704.

Nath, D., \& Sudharshan, D. (1994). Measuring strategy coherence through patterns of strategic choices. Strategic Management Journal, 15, 43-61.

Nwokah, N. G. (2008). Strategic market orientation and business performance: The study of food and beverages organizations in Nigeria. European Journal of Marketing, 42, 279-286.

O'Regan, N., \& Ghobadian, A. (2006). Perceptions of generic strategies of small and medium sized engineering and electronics manufacturers in the UK: The applicability of the Miles and Snow typology. Journal of Manufacturing Technology Management, 17, 603-620.

Palepu, K. (1985). Diversification strategy, profit performance and the entropy measure. Strategic Management Journal, 6, 239-255.

Pappas, J. M., \& Wooldridge, B. (2007). Middle managers' divergent strategic activity: An investigation of multiple measures of network centrality. Journal of Management Studies, 44, 323-341.

Parnell, J. A. (1997). New evidence in the generic strategy and business performance debate: A research note. British Journal of Management, 8, 175-181.

Parnell, J. A. (2008). Sustainable strategic management: Construct, parameters, research directions. International Journal of Sustainable Strategic Management, 1(1), 35-45.

Parnell, J. A., O'Regan, N., \& Ghobadian, A. (2006). Measuring performance in competitive strategy research. International Journal of Management and Decision Making, 7, 408-417.

Penrose, E. (1959). The theory of the growth of the firm. New York: Sharpe.

Peteraf, M. A. (1993). The cornerstones of competitive advantage: A resource-based view. Strategic Management Journal, 14, 179-191.

Petersen, B., \& Welch, D. E. (2000). Creating meaningful switching options in international operations. Long Range Planning, 33, 688-705.

Phelan, S. E., Ferreira, M., \& Salvador, R. (2002). The first twenty years of the Strategic Management Journal. Strategic Management Journal, 23, 1161-1168.

Pongatichat, P., \& Johnston, R. (2008). Exploring strategymisaligned performance measurement. International Journal of Productivity and Performance Management, 57(3), 207-222.

Porter, M. E. (1980). Competitive strategy. New York: Free Press.

Porter, M. E. (1981). The contributions of industrial organization to strategic management. Academy of Management Review, 6, 609-620.

Porter, M. E. (1985). Competitive advantage. New York: Free Press.
Porter, M. E. (1996). What is strategy? Harvard Business Review, 74(6), 61-78.

Powell, T. C. (1996). How much does industry matter? An alternative empirical test. Strategic Management Journal, 17, 323-334.

Ramaswamy, K., Veliyath, R., \& Gomes, L. (2000). A study of the determinants of CEO compensation in India. Management International Review 40, 167-191.

Reed, R., \& DeFillippi, R. J. (1990). Causal ambiguity, barriers to imitation, and sustainable competitive advantage. Academy of Management Review, 15, 88-102.

Richter, A., \& Schmidt, S. L. (2005). How does strategy process influence strategy content? Antecedents of consistency between resource allocation decisions and corporate strategy. Schmalenbach Business Review, 57, 332-351.

Robins, J., \& Wiersema, M. F. (1995). A resource-based approach to the multibusiness firm: Empirical analysis of portfolio interrelationships and corporate financial performance. Strategic Management Journal, 16, 277-299.

Roquebert, J. A., Phillips, R. L., \& Westfall, P. A. (1996). Markets vs. management: What "drives" profitability? Strategic Management Journal, 17, 653-664.

Rouleau, L. (2005). Micro-practices of strategic sensemaking and sensegiving: How middle managers interpret and sell change every day. Journal of Management Studies, 42, 1413-1441.

Rugman, A. M., \& Verbeke, A. (2008). The theory and practice of regional strategy: A response to Osegowitsch and Sammartino. Journal of International Business Studies, 39, 326-332.

Rumelt, R. (1984). Towards a strategic theory of the firm. In R. Lamb (Ed.), Competitive strategic management (pp. 556570). Englewood Cliffs, NJ: Prentice-Hall.

Sangle, S., \& Babu, P. R. (2006). Neural network model for identification of societal preference of environmental issues. International Journal of Environment \& Pollution, 28(3/4), 326-351.

Sangle, S., \& Babu, P. R. (2007). Evaluating sustainability practices in terms of stakeholders' satisfaction. International Journal of Business Governance and Ethics, 3(1), 56-76.

Selsky, J. W., Goes, J., \& Baburoglu, O. N. (2007). Contrasting perspectives of strategy making: Applications in 'hyper' environments. Organization Studies, 28, 71-94.

Seth, A., \& Thomas, H. (1994). Theories of the firm: Implications for strategy research. Journal of Management Studies, 31, 165-191.

Service, R. (2006). The development of strategic intelligence: A managerial perspective. International Journal of Management, 23(1), 61-77.

Sheehan, N. T., \& Foss, N. J. (2007). Enhancing the prescriptiveness of the resource-based view through Porterian activity analysis. Management Decision, 45, 450-461.

Smircich, L., \& Stubbart, C. (1985). Strategic management in an enacted world. Academy of Management Review, 10, 724736.

Sorge, A., \& Brussig, M. (2003). Organizational process, 
strategy content, and socio-economic resources: Small enterprises in East Germany, 1990-94. Organization Studies, 24, 1261-1281.

Spanos, Y. E., Zaralis, G., \& Lioukas, S. (2004). Strategy and industry effects on profitability: Evidence from Greece. Strategic Management Journal, 25, 139-165.

Stead, J. G., \& Stead, W. E. (2000). Eco-enterprise strategy: Standing for sustainability. Journal of Business Ethics, 24(4), 313-329.

Stead, W. E., \& Stead, J. G. (1994). Can humankind change the economic myth? Paradigm shifts necessary for ecologically sustainable business. Journal of Organizational Change Management, 7(4), 15-31.

Stead, W. E., \& Stead, J. G. (2004). Sustainable strategic management. Armonk, NY: M. E. Sharpe.

Svensson, G. (2006). Sustainable quality management: A strategic perspective. The TQM Magazine, 18(1), 22-29.

Thomas, A. S., \& Ramaswamy, K. (1996). Matching managers to strategy: Further tests of the Miles and Snow typology. British Journal of Management, 7, 247-261.

Thomas, H., \& Venkatraman, N. (1988). Research on strategic groups: Progress and proposals. Journal of Management Studies, 25, 537-555.

Thorpe, E. R., \& Morgan, R. E. (2007). In pursuit of the "ideal approach" to successful marketing strategy implementation. European Journal of Marketing, 41, 659-677.

Trim, P., \& Lee, Y. (2007). Placing organizational learning in the context of strategic management. Business Strategy Series, 8(5), 335-342.

Ulrich, D. (1987). The population perspective: Review, critique, and relevance. Human Relations, 40, 137-152.

Van de Ven, A. H., \& Johnson, P. E. (2006). Knowledge for theory and practice. Academy of Management Review, 31, 802-821.

Van der Stede, W. A., Chow, C. W., \& Lin, T. W. (2006). Strategy, choice of performance measures, and performance. Behavioral Research in Accounting, 18, 185-205.

Varadarajan, P. R. (1999). Strategy content and process perspectives revisited. Academy of Marketing Science, 27(1), 88-100.

Venkatraman, N., \& Ramanujam, V. (1986). Measurement of business performance in strategy research: A comparison of approaches. Academy of Management Review, 11, 801-814.

Wallace, N. D., III, Worrell, D. L., \& Nemec, C. (1998). CEO duality, succession-planning and agency theory: Research agenda. Strategic Management Journal, 19, 905-908.

Webb, J., \& Dawson, P. (1991). Measure for measure: Strategic change in an electronic instruments corporation. Journal of Management Studies, 28, 191-206.

Wernerfelt, B. (1984). A resource-based theory of the firm. Strategic Management Journal, 5, 171-180.

Wernerfelt, B., \& Karnani, A. (1987). Competitive strategy under uncertainty. Strategic Management Journal, 8, 187194.

West, G. P., III. (2007). Collective cognition: When entrepreneurial teams, not individuals, make decisions. Entrepreneurship Theory and Practice, 31(1), 77-102.

Westphal, J. D., \& Fredrickson, J. W. (2001). Who directs strategic change? Director experience, the selection of new CEOs, and change. Strategic Management Journal, 22, 1113-1137.

Whinston, M. D. (2003). On the transaction cost determinants of vertical integration. Journal of Law, Economics \& Organization, 19(1), 1-24.

Whipp, R., Rosenfeld, R., \& Pettigrew, A. (1989). Managing strategic change in a mature business. Long Range Planning, 22(6), 92-99.

Williamson, O. E. (1985). The economic institutions of capitalism: Firms, markets, relational contracting. New York: Free Press.

Wooldridge, B., \& Floyd, S. W. (1990). The strategy process, middle management involvement, and organizational performance. Strategic Management Journal, 11, 231-241.

Wright, P., Kroll, M., Pringle, C., \& Johnson, J. (1990). Organization types, conduct, profitability and risk in the semiconductor industry. Journal of Management Systems, 2(2), 33-48.

Zahra, S.A. (1993). Environment, corporate entrepreneurship, and financial performance: A taxonomic approach. Journal of Business Venturing, 8, 319-340.

Zaima, J. K., Turetsky, H. F., \& Cochran, B. (2005). The MVAEVA relationship: Separation of market driven versus firm driven effects. Review of Accounting \& Finance, 4(1), 32-49.

\section{Footnotes}

* Correspondence with the author to jparnell@jparnell.com 